\title{
Agroterrorism Targeting Livestock: A Review with a Focus on Early Detection Systems
}

\author{
Armin Elbers and Rickard Knutsson
}

Agroterrorism targeting livestock can be described as the intentional introduction of an animal disease agent against livestock with the purpose of causing economic damage, disrupting socioeconomic stability of a country, and creating panic and distress. This type of terrorism can be alluring to terrorists because animal disease agents are easily available. This review addresses the vulnerabilities of the livestock industry to agroterrorism. However, we also show that early detection systems have recently been developed for agroterrorism and deliberate spread of animal pathogens in livestock, including an agroterrorism intelligence cycle, syndromic surveillance programs, and computer-based clinical decision support systems that can be used for early detection of notifiable animal diseases. The development of DIVA-vaccines in the past 10 to 15 years has created, in principle, an excellent response instrument to counter intentional animal disease outbreaks. These developments have made our animal agriculture less vulnerable to agroterrorism. But we cannot relax; there are still many challenges, in particular with respect to integration of first line of defense, law enforcement, and early detection systems for animal diseases.

A GROTERRORISM TARGETING LIVESTOCK can be described as the intentional introduction of an animal disease agent into livestock with the purpose of causing economic damage, disrupting the socioeconomic stability of a country, and creating panic and distress. ${ }^{1,2}$ Intentional introduction of animal diseases is not common, but livestock have been targets of biological warfare or bioterrorism incidents. ${ }^{3,4}$ Biological weapons for livestock have been developed; for instance, Germany had biological weapons research on foot-and-mouth disease (FMD) and rinderpest, and Russia developed biological weapons research on African swine fever (ASF), FMD, and rinderpest. The United States, Canada, and the United Kingdom have investigated diseases such as anthrax, brucellosis, and glanders, and the British developed 5 million "cattle cakes" with anthrax spores, which were supposed to have been dropped on German grazing lands during World War II. ${ }^{5}$ The modus operandi and motives for terrorists attacking livestock cover a broad spectrum, ranging from individuals, to companies, to countries causing mass casualties in animals, humans, or both. ${ }^{6}$

Although agriculture may not be a terrorist's first choice, because it lacks the shock value of more traditional terrorist targets, many analysts consider it a viable secondary target. Agriculture has several characteristics that pose unique vulnerabilities. Farms are geographically disbursed in unsecured environments. Livestock are frequently concentrated in confined locations and transported or commingled with other herds. ${ }^{7,8}$ The continuing trends of intensive production techniques, the vertical integration of the production continuum, increasing dependence on the export market, and the lack of resistance to pathogens that prevail in some countries are other factors contributing to the vulnerability of the livestock industry. ${ }^{7-11}$

Armin Elbers, PhD, MSc Ag, MSc PopMed, is a senior scientist and epidemiologist in the Department of Epidemiology, Crisis Organisation and Diagnostics, Central Veterinary Institute (CVI) of Wageningen University, The Netherlands. Rickard Knutsson, $\mathrm{PhD}$, is Director of Security Department, National Veterinary Institute (SVA), Uppsala, Sweden. 
Over the past century, there has been a shift away from livestock production as a highly localized enterprise, where animals were typically born, fattened, and slaughtered in the same region. This change presents an opportunity for pathogens to be introduced and to spread long distances in a single incubation period before a significant number of animals appear ill. ${ }^{12}$ Mass animal movement may provide a built-in dispersal mechanism for bioterror agents. ${ }^{13} \mathrm{Simu}$ lation studies in the United States suggest that FMD would quickly spread beyond control once it is introduced. ${ }^{14}$

The biological, economic, and political impacts of agroterrorism have generated international concern, ${ }^{15}$ and since 2005, 4 International Symposia on Agroterrorism (ISA) have been organized. The fourth ISA took place in Kansas City in April 2011, and more than 1,000 individuals from 25 different counties have participated in past ISA meetings. ${ }^{16}$

Many agricultural diseases can be obtained, handled, and distributed easily. International trade in food products often is tied to disease-free status, which could be jeopardized by an attack. ${ }^{17}$ Many veterinarians lack experience with foreign animal diseases that have been eradicated domestically but remain endemic in other countries.

The use of animal disease agents against livestock in agroterrorism attacks between 1900 and 1998 has been carefully reviewed; ${ }^{18,19}$ the reviews indicated that such an event is very rare compared to attacks against other targets. However, an agroterrorism attack requires relatively little expertise or technology. ${ }^{20}$ Many notifiable animal diseases are highly contagious and spread effectively from a source, as demonstrated by recent epidemics of FMD, classical swine fever (CSF), highly pathogenic avian influenza (HPAI), Newcastle disease (ND), and bluetongue. ${ }^{21-26}$ Moreover, terrorists can safely handle most of the causative agents with no risk of becoming infected themselves. For several of these pathogens, trade sanctions are imposed in the wake of outbreaks, so even a small outbreak can have very large economic effects. An example of a small outbreak that generated many countermeasures was an outbreak of anthrax that occurred in 2008 in a beef cattle herd in the south of Sweden. ${ }^{27}$ Only 1 farm with a single herd was infected, but it resulted in one of the most costly decontamination procedures ever undertaken in Sweden.

Animal agriculture is a vital part of the economy in many developed countries. According to Chalk, ${ }^{15}$ there are at least 3 levels of costs associated with an agroterrorism attack: (1) direct losses resulting from containment measures and the destruction of diseased livestock; (2) compensation costs paid to farmers for the destruction of agricultural commodities and losses suffered by both directly and indirectly related industries; and (3) international costs in the form of protective trade embargoes imposed by major external trading partners. Table 1 gives an overview of direct and indirect costs involved in recent epidemics of notifiable animal diseases and shows that outbreaks of these animal diseases can have a devastating economic impact. For the
United States and Australia, free of FMD for several decades, it is estimated that introduction of FMD and subsequent spread of the disease would cost approximately US $\$ 14$ billion and US\$5-12 billion, respectively. ${ }^{53,54}$ A recent report from the World Bank concluded that early control of animal and zoonotic diseases are costeffective and prevent human disease. ${ }^{55}$

\section{Differentiating Between Natural and Intentional Outbreaks}

Thanks to modern animal husbandry and management and advances in veterinary medicine, the frequency of major animal disease epidemics has been greatly reduced. ${ }^{2}$ For instance, it was not unusual to have thousands of outbreaks of FMD and CSF for many years between the 1930s and the 1960s in the Netherlands. ${ }^{56}$ The features of naturally occurring outbreaks have a certain predictability in terms of consistency with previous occurrences, or at least a biological plausibility. However, with the intentional introduction of an infection into an (animal) population, this predictability is reduced. ${ }^{57}$ An epidemiologic investigation of a covert attack differs little from that conducted following a naturally occurring outbreak. ${ }^{9,58}$ Certain characteristics of an animal disease outbreak, although perhaps not indicative of a covert attack when considered singly, when combined with other observations may provide convincing evidence of intentional causation. The technical ease of introducing many pathogens makes it more likely that agroterrorists would release pathogens in several locations in an attempt to initiate multiple simultaneous outbreaks. This is the principal way in which an agroterrorism attack would differ from a natural disease outbreak. ${ }^{20}$ This would ensure that trade sanctions would be imposed, because it would undermine any argument that the outbreaks are localized. It would probably overwhelm the response capacity and lead to the uncontrollable spread of the disease. Furthermore, an unusual presentation of clinical signs, perhaps from an atypical route of exposure, also may provide useful forensic evidence. ${ }^{59}$

Other potential factors differentiating intentional from natural outbreaks include the disease's season and geographic presentation, variants or unusual strains of pathogens or antimicrobial resistance patterns that are different from those that are circulating, morbidity and mortality rates that are out of the normal expected range, concurrence with threats or hoaxes, and direct evidence of the release of a pathogen, with findings of equipment, munitions, or tampering. $57,59,60$

The US Department of Agriculture (USDA) has developed a template for differentiation of naturally occurring from non-naturally occurring epizootics of anthrax in livestock populations. ${ }^{61}$ The methodology is intended to be used by veterinary practitioners or other early responders in the field to an anthrax incident. Approximately 20 
Table 1. Economic Costs of Some Notifiable Animal Disease Outbreaks

\begin{tabular}{|c|c|c|c|c|c|c|c|}
\hline $\begin{array}{l}\text { Animal } \\
\text { Disease }\end{array}$ & Country & Year & $\begin{array}{c}\text { No. } \\
\text { Affected } \\
\text { Herds }\end{array}$ & $\begin{array}{c}\text { No. Culled } \\
\text { Animals }\end{array}$ & $\begin{array}{c}\text { Direct Costs } \\
\text { in Millions } \\
\text { (currency) }\end{array}$ & $\begin{array}{c}\text { Indirect Costs } \\
\text { in Millions } \\
\text { (currency) }\end{array}$ & Reference \\
\hline Anthrax & Sweden & 2008 & 1 & 78 & 60 (SEK) & & 28 \\
\hline HPAI & USA & 1983-84 & unknown & 17 million & 60 (US\$) & & 29 \\
\hline HPAI & Italy & 1999 & 413 & 16 million & $112(€)$ & $395(€)$ & 30 \\
\hline HPAI & Netherlands & 2003 & 255 & 30 million & $300(€)$ & $700(€)$ & 31,32 \\
\hline HPAI & Canada & 2004 & 42 & 17 million & $380(\mathrm{US} \$)$ & & 33 \\
\hline LPAI & USA & $1997-98$ & 18 & unknown & 3.5 (US\$) & & 34 \\
\hline LPAI & Italy & 2000-01 & 80 & 1.7 million & $10(€)$ & & 35 \\
\hline LPAI & Italy & $2002-03$ & 388 & 7.6 million & $40(€)$ & & 35 \\
\hline ND & USA & $2002-03$ & 912 & 3.2 million & $221(\mathrm{US} \$)$ & $121(\mathrm{US} \$)$ & 36 \\
\hline ND & Northern Ireland & 1997 & 26 & 546,000 & $3.5(£)$ & & 37 \\
\hline CSF & Belgium & 1990 & 113 & 1 million & $212(€)$ & & 38 \\
\hline CSF & Belgium & 1993-94 & 52 & 743,871 & $75(€)$ & & 39 \\
\hline CSF & Belgium & 1997 & 8 & 74,140 & $10(€)$ & & 40 \\
\hline CSF & Netherlands & $1997-98$ & 429 & 12 million & $1,320(€)$ & $1,020(€)$ & 41 \\
\hline FMD & Italy & 1993 & unknown & 8,000 & 11.5 (US\$) & 120 (US\$) & 42 \\
\hline FMD & UK & 2001 & 2,030 & 6.1 million & $3,125(£)$ & $4,000(£)$ & 43,44 \\
\hline FMD & Netherlands & 2001 & 26 & 260,000 & $273(€)$ & $1,027(€)$ & 45,46 \\
\hline FMD & Taiwan & 1997 & 6,147 & 4 million & 379 (US\$) & 1,300 (US\$) & 47 \\
\hline FMD & South Korea & 2010-11 & 157 & 9.7 million & 2,700 (US\$) in 2010 & & 48 \\
\hline Nipah & Malaysia & $1998-99$ & 946 & 1 million & 233 (US\$) & 267 (US\$) & 49,50 \\
\hline Bluetongue & Netherlands & 2006-07 & 6,480 & 0 & $32(€)$ & & 51 \\
\hline Q fever & Netherlands & $2007-10$ & 88 & 50,000 & $27(€)$ & $134-308(€)$ & 52 \\
\hline
\end{tabular}

Note: HPAI: highly pathogenic avian influenza; LPAI: low pathogenic avian influenza; ND: Newcastle disease; CSF: classical swine fever; FMD: footand-mouth disease.

ecological and epidemiologic criteria are to be evaluated in order to differentiate a natural epizootic anthrax incident from a non-natural one.

\section{Potential for Agroterrorism}

Biological warfare programs, including biological weapons against livestock, are prohibited by the Convention on the Prohibition of the Development, Production and Stockpiling of Bacteriological (Biological) and Toxin Weapons and on Their Destruction (commonly known as the Biological Weapons Convention, or BWC) under the regula- tion of the United Nations. ${ }^{62}$ Of the hundreds of animal pathogens and pests available to an agroterrorist, perhaps fewer than a couple dozen represent significant economic threats. ${ }^{1,19}$ Determinants of this level of threat are the agents' pathogenicity, contagiousness, and potential for rapid spread across international borders; low levels of immunity to the agent in the target population; ${ }^{63}$ and the potential to inflict catastrophic economic losses and social disruption, condensed in its international status as a reportable pest or disease under rules of the World Organization for Animal Health (OIE) ${ }^{64}$ The US Agricultural Bioterrorism Protection Act of $2002^{65}$ created a list of potential animal pathogens that draws heavily from the 
former List A and B diseases of the OIE. The list is specified in the select agent rules implemented by the Animal and Plant Health Inspection Service (APHIS) of the USDA ${ }^{66}$ (Table 2). The animal diseases on the select agent list of the Centers for Disease Control and Prevention $(C D C)^{67}$ are diseases that pose a risk to both human and animal health. The Australia Group, which is an informal forum of countries, has made a list of designated animal diseases with export controls to ensure that exports do not contribute to the development of chemical or biological weapons. ${ }^{68,69}$ The Australia Group activities serve to support the objectives of the BWC by harmonizing export controls; their list of animal diseases and agents is shown in Table 2. Others have added a few other diseases as potential bioterrorism agents, ${ }^{19}$ including pseudorabies virus, ornithosis/psittacosis, porcine reproductive and respiratory syndrome virus, lyssaviruses and rabies viruses, and screwworm myiasis.

The European Commission is currently working on the implementation (2010-2014) of the EU (European Union) CBRN Action Plan, and 1 Action (H1) focuses on the establishment of EU lists that includes high-risk biological agents and toxins, including animal pathogens. ${ }^{70}$

\section{Early Detection Systems}

We must be prepared for the introduction of an exotic (animal) disease, and if an outbreak occurs, we must act without hesitation. "By preparing for the norm, one is prepared for the abnormal," note Hugh-Jones and Brown. ${ }^{2(\mathrm{p} 24)}$ In principle, an effective response to an intentional agroterrorism attack is no different from that of an effective response to a natural introduction of exotic diseases. ${ }^{20}$ Since the anthrax cases in 2001, development and use of syndromic surveillance has been promoted for early detection of infectious diseases and preparing antibioterrorism measures. ${ }^{71}$

Several surveillance systems for early detection of bioterrorism-related diseases exist and have been reviewed..$^{72,73}$ Since September 11 and the anthrax letters, huge efforts have been made to develop early detection methods as part of bioterrorism preparedness, but unquestionably the experience and expertise of field and laboratory personnel are crucial to detecting an index case as quickly as possible. ${ }^{74}$

\section{First Line of Defense: Customs and Law Enforcement}

Traditionally, the first line of defense against a foreign animal disease has been to try to keep it from entering the country. ${ }^{1}$ In today's interconnected global industries and economies, and with the intercontinental transport of foodstuffs, both legal and illegal, pathogens are moved globally in spite of restrictions. ${ }^{75-78}$ Meat and meat products may be contaminated with dangerous pathogens like
Table 2. Lists of Animal Diseases on Bioterrorism Lists and with Export Controls

\begin{tabular}{|c|c|c|c|}
\hline Disease/Agent & $A P H I S^{66}$ & $C D C^{67}$ & $A G^{68,69}$ \\
\hline African horse sickness (AHS) & $\mathrm{X}$ & & $\mathrm{X}$ \\
\hline African swine fever (ASF) & $\mathrm{X}$ & & $\mathrm{X}$ \\
\hline Anthrax (Bacillus anthracis) & $\mathrm{X}$ & $\mathrm{X}$ & $\mathrm{X}$ \\
\hline Avian influenza (AI) & $\mathrm{X}$ & & $\mathrm{x}$ \\
\hline Bluetongue & & & $\mathrm{X}$ \\
\hline Botulism (Clostridium botulinum) & $\mathrm{x}$ & $\mathrm{X}$ & $\mathrm{x}$ \\
\hline Brucellosis of cattle (Brucella abortus) & $\mathrm{x}$ & $\mathrm{X}$ & $\mathrm{X}$ \\
\hline $\begin{array}{l}\text { Brucellosis of sheep (Brucella } \\
\text { melitensis) }\end{array}$ & $\mathrm{x}$ & $\mathrm{X}$ & $\mathrm{X}$ \\
\hline Brucella of pigs (Brucella suis) & $\mathrm{x}$ & $\mathrm{x}$ & $\mathrm{X}$ \\
\hline Chlamydophila psittaci & $\mathrm{X}$ & $\mathrm{x}$ & \\
\hline Classical swine fever (CSF) & $\mathrm{X}$ & & $\mathrm{X}$ \\
\hline Contagious bovine pleuropneumoniae & $\mathrm{X}$ & & $\mathrm{X}$ \\
\hline $\begin{array}{l}\text { Contagious caprine } \\
\text { pleuropneumoniae }\end{array}$ & $\mathrm{X}$ & & $\mathrm{X}$ \\
\hline Eastern equine encephalitis & $\mathrm{X}$ & $\mathrm{X}$ & $\mathrm{X}$ \\
\hline Foot-and-mouth disease (FMD) & $\mathrm{x}$ & & $\mathrm{X}$ \\
\hline Glanders (Burkholderia mallei) & $\mathrm{x}$ & $\mathrm{x}$ & \\
\hline Goat pox & $\mathrm{x}$ & & $\mathrm{X}$ \\
\hline Hendra virus (of horses) & $\mathrm{x}$ & & $\mathrm{X}$ \\
\hline Lumpy skin disease & $\mathrm{X}$ & & $\mathrm{X}$ \\
\hline Lyssa virus & & & $\mathrm{X}$ \\
\hline $\begin{array}{l}\text { Melioidosis (Burkholderia } \\
\text { pseudomallei) }\end{array}$ & $\mathrm{x}$ & $\mathrm{X}$ & $\mathrm{X}$ \\
\hline Newcastle disease (ND) & $\mathrm{X}$ & & $\mathrm{X}$ \\
\hline Nipah virus (of pigs) & $\mathrm{x}$ & & $\mathrm{X}$ \\
\hline Peste des petits ruminants & $\mathrm{x}$ & & $\mathrm{X}$ \\
\hline Pseudorabies & & & $\mathrm{X}$ \\
\hline Q fever (Coxiella burnetii) & $\mathrm{X}$ & $\mathrm{x}$ & $\mathrm{X}$ \\
\hline Rift Valley fever & $\mathrm{X}$ & & $\mathrm{X}$ \\
\hline Rinderpest & $\mathrm{X}$ & & $\mathrm{X}$ \\
\hline Sheep pox & $\mathrm{X}$ & & $\mathrm{X}$ \\
\hline Swine vesicular disease (SVD) & $\mathrm{X}$ & & $\mathrm{X}$ \\
\hline Teschen disease virus & & & $\mathrm{X}$ \\
\hline Tularemia (Francisella tularensis) & $\mathrm{X}$ & $\mathrm{X}$ & $\mathrm{X}$ \\
\hline Venezuelan equine encephalitis & $\mathrm{x}$ & $\mathrm{X}$ & $\mathrm{X}$ \\
\hline Vesicular stomatitis & $\mathrm{x}$ & & $\mathrm{x}$ \\
\hline Western equine encephalitis & & $\mathrm{X}$ & $\mathrm{X}$ \\
\hline
\end{tabular}

Biosecurity and Bioterrorism: Biodefense Strategy, Practice, and Science 
FMD virus, ASF, and CSF virus. National regulations are in force to prevent the importation of such pathogens, but the illegal importation of meat provides a route by which controls may be circumvented and pathogens introduced. A quantitative risk assessment study for the United Kingdom estimated, based on seizures of products of animal origin (smuggled products in freight, both air and sea; mail; and passenger baggage), the amount of illegal meat imported on an average to be about 12,000 tons per year. ${ }^{79}$ The National Veterinary Research and Quarantine Services (NVRQS) of South Korea detected about 36 tons of smuggled meat in $2003 .{ }^{80}$ It is assumed that between 50\% and $90 \%$ of contraband food of animal origin in passenger baggage at airports in South Korea escapes interception. In 1999, Taiwanese authorities seized some 1,000 tons of meat products smuggled into Taiwan from the People's Republic of China, and this may represent only $10 \%$ of the total amount actually reaching its destination. ${ }^{81}$ Chaber et $\mathrm{al}^{82}$ estimated that about 5 tons of bushmeat per week is smuggled in personal baggage through Paris Roissy-Charles de Gaulle Airport in France.

It is clear that well-equipped and well-staffed customs agencies and border patrols are a necessary first line of defense against illegal introduction of such pathogens into countries that are free of these pathogens. ${ }^{83}$ But professional surveillance at our borders will not be enough to protect us from intentional or unintentional introduction of animal pathogens. ${ }^{7}$ Simple means can be used to smuggle many of the most dangerous animal pathogens, further confounding efforts to prevent their intentional introduction. When pathogens are introduced and have infected livestock, surveillance systems should be in operation for early detection to prevent spread of the disease.

Recently, an agroterrorism intelligence cycle aimed at focusing on early detection of an agroterrorism incident has been proposed. ${ }^{84}$ It outlines a framework for detecting intention using open source and overt electronic data. The role of first responders in agroterrorism is not always clear, ${ }^{85}$ so a guidebook for first responders related to agroterrorism has been developed. ${ }^{86}$ A criminal investigation handbook for agroterrorism ${ }^{87}$ is available mainly for law enforcement officials but may also be useful for others involved in surveillance; it includes a list of indications of accidental or intentional threats to the food supply.

\section{Surveillance Systems}

The key prerequisite for any effective surveillance system is knowledge of the baseline disease prevalence and mortality. Without this information, it is impossible to tell whether disease occurrences are below or above the threshold for special action. Furthermore, timely knowledge of key production variables will allow early detection of adverse health events. ${ }^{10}$ For instance, a drop in egg production and a decrease in feed intake preceded the exponential increase in mortality during the H7N7 HPAI epidemic in 2003 in the Netherlands. ${ }^{88}$ Above baseline mortality in the index case was observed at the start of the CSF epidemic in 1997 in the Netherlands. ${ }^{21}$ Thus, farmers are key players in a surveillance system because they are the first to notice an aberration in the normal situation. ${ }^{56}$

To facilitate reporting of incidents of herd health problems by farmers, a consultancy help desk (Veekijker) was developed at the Animal Health Service (GD) in the Netherlands. ${ }^{89}$ The purpose of Veekijker is to detect exotic and new diseases by combining a second-line consultancy desk with the tasks of collecting and evaluating information. This information collection is passive; farmers and private veterinarians must initiate contact with Veekijker. In cases of incidents or herd health problems that are not fully understood, both farmers and, especially, veterinarians are encouraged to contact Veekijker through a nationally publicized telephone number. Calls are handled by a consistent group of 5 cattle health specialists. When necessary, the specialists visit the farms for free to pursue more detailed information. To further motivate farmers and veterinarians to contact Veekijker, regular feedback of information is provided on websites and in magazines, presentations, and newsletters. Similar systems, but predominantly focused on veterinary practitioners reporting extraordinary cases, have been developed in France (Émergences), ${ }^{90}$ the United States (RSVP-A), ${ }^{91}$ and New Zealand (VetPAD). ${ }^{92}$ These all have the disadvantage that they can report only on possible suspect cases for which they have been called in by farmers, and, in addition, there might be a time lag between first clinical signs seen by farmers and their asking for the veterinarian's opinion. In New Mexico, a syndromic surveillance program has been developed for the early detection of animal disease outbreaks caused by either natural or intentional spread of pathogens. $^{93}$

Another prerequisite for responding to a bioattack against livestock is the ability to recognize the signs and symptoms of likely disease agents. Because notifiable animal diseases like FMD, AI, ND, and CSF are exotic in many countries and may not have been seen for decades, farmers and veterinary practitioners often do not think of these diseases in the differential diagnosis as a cause of the clinical problems they observe. ${ }^{94}$ Continuing education in recognizing clinical signs associated with notifiable animal diseases is therefore very important. ${ }^{10,56}$ As an example, an instrument to help in recognizing pig diseases in the Netherlands was developed by research institutes, supported financially by the Dutch Product Board for Livestock and Meat and the Ministry of Agriculture. A website (www.varkensziekte.nl) was built with pictures and moving images of clinical signs of CSF and other notifiable animal diseases like FMD, swine vesicular disease (SVD), and pseudorabies, and pictures and information on 20 other endemic pig diseases. A simple decision tree helps visitors to the website to get a first impression of which diseases might have caused the clinical problems, and they are advised to contact a veterinary practitioner. 
In theory, reporting of notifiable animal diseases by farmers to the veterinary authorities can be an effective early detection tool. Therefore, formal rules for reporting clinically suspect situations in livestock by farmers and veterinary practitioners are laid out in national and international legislation. In the Netherlands, the Dutch Cattle Act was officially put into force in $1870 .^{95}$ It consisted of a list of contagious diseases like rinderpest, anthrax, rabies, and FMD. It also contained regulations for isolation of affected and suspect livestock, notification of affected and suspect livestock to the mayor of the municipality, obligatory notification by veterinary practitioners, and prohibition of transport of sick and suspect livestock. In essence, not much has changed with respect to the reporting and eradication process of notifiable animal diseases since those early days. One of the first actions a veterinary practitioner or farmer should take when they suspect a natural or intentional animal disease outbreak is timely reporting to competent authorities. $^{10}$

However, diagnosis of CSF, FMD, or AI based on clinical signs is often difficult, because these diseases are unfamiliar to farmers and sometimes veterinary practitioners, and also because signs may vary considerably, depending on the age and/or breed of the affected animals and the virulence of the virus strain. ${ }^{94,96}$ Thus, laboratory diagnostic confirmation is necessary. In many national regulations, however, laboratory confirmation is allowed only after reporting to the veterinary authorities. This sometimes leads to control measures being imposed-for example, isolation of the farm - until the results of diagnostic testing are available. Isolation of the farm, especially if it lasts for several days, may have negative economic consequences for the farmer. Furthermore, many endemic animal diseases cause clinical signs similar to those of notifiable animal diseases, especially in the early stages of the disease process. After a considerable period of freedom from notifiable animal diseases in a country, farmers and vets will have a tendency to think that clinical signs they observe are caused by the endemic disease and not by a notifiable animal disease. These phenomena sometimes cause farmers and veterinarians to be reluctant to report early clinical signs of notifiable animal diseases, meaning that the time needed for ultimate detection of a new infection provides time for the disease agent to spread. For instance, many case reports indicated that CSF was suspected only after prolonged use of medication had failed to produce desired results. ${ }^{21}$

Experience shows that epidemics of notifiable animal diseases in densely populated livestock areas are difficult to control, especially if the detection of the index case is delayed. ${ }^{21,88,97-99}$ The length of the high-risk period is one of the most important parameters that determine the magnitude of an outbreak because it defines the period in which the disease agent can circulate freely and is able to spread to other livestock premises. The high-risk period begins when the first animal is infected and ends when all eradication measures are in full operation-that is, the region concerned no longer presents any risk to other regions. The consequence of delayed reporting of a clinically suspect situation is a longer high-risk period. This will seriously hamper the eradication of the disease agent after it is introduced into a country that was previously free of the agent because disease may have spread to other farms. Problems with timely reporting (by the farmer or veterinarian) to the appropriate authorities of a clinically suspect situation on livestock farms is a worldwide problem. ${ }^{100}$ Reporting could be facilitated by transparent communication of the processes involved in reporting; the farmer will be less frightened and stressed if he knows what to expect when he reports a suspect situation. Transparency of the reporting process will also help to rebuild trust between the farming community and the authorities.

Measures that facilitate the use of exclusion diagnostics in a clinical situation with nonspecific clinical signs would be helpful. ${ }^{100}$ The poultry farmer's ability to submit swabs or tissue and blood samples at no cost would help to exclude AI in a clinical situation with nonspecific clinical signs, in particular if this has no consequences for the farm operations. Such a system has been operational in the Netherlands for 2 years. ${ }^{101}$ Obviously, one has to select appropriate samples based on post mortem examination in combination with certain preliminary diagnoses from veterinary poultry practices to be submitted to the National Reference Lab for PCR testing to exclude AI as a possible cause for the disease problems in poultry flocks. A similar approach was developed for the swine industry: When nonspecific clinical signs are seen on swine farms, and CSF cannot be excluded clinically, there is reason to submit samples from sick swine to a reference laboratory to check for CSF infection, without isolation of the farm. ${ }^{102,103}$ However, even when such a system does exist (eg, in the Netherlands and in Germany), farmers do not always use it as often as we would like them to. After the successful introduction of the system in the Netherlands in 2006, the number of submissions of samples for exclusion diagnostics has declined dramatically for several years. ${ }^{104}$ Asked for their opinion, swine farmers and practitioners indicated that they were not satisfied with the current distribution of the costs involved in using exclusion diagnostics. ${ }^{102}$ The costs of the PCR test, the costs of the veterinary practitioner, and the costs for shipping the samples to the reference laboratory should, in their view, be paid for by the Animal Health Fund (a fund from which the direct costs of eradicating a notifiable animal disease are financed; it is filled $50 \%$ by government and $50 \%$ by industry) or by the government. It can be concluded that great improvements have been made in the past few years to facilitate the use of exclusion diagnostics, but there is still room for progress to be made.

Summarizing, early detection of the index case is crucial, and the collaboration between clinicians and farmers is essential to minimize the length of the high-risk period. Agroterrorism threats generate needs for multisectoral early 
detection systems. Integration of the first line of defense and law enforcement with existing early detection systems for animal diseases is therefore a challenge. To improve future systems for early detection of deliberate spread of animal diseases, the animal health sector needs to collaborate with law enforcement. In the long run, this will require further research and development but also training and education to build a collaborative culture between the sectors.

\section{RESPONSE}

The response to covert and overt agroterrorism incidents is challenging. Covert and overt incidents will lead to various alarm chains. In a covert incident, which is characterized by an unannounced release, the early response and detection will be driven by public health organizations. But an overt incident is characterized by the perpetrators announcing responsibility, and the response will therefore be driven by law enforcement. As a result, response strategies must be able to face both types of incidents. This requires a multidisciplinary network of diagnostic capabilities both in law enforcement agencies and public health organizations that can respond to environmental, agricultural, veterinary, and food threats. ${ }^{105}$ In addition to diagnostic capabilities, vaccination preparedness is crucial. ${ }^{20,106}$

After a long period of being disease free, the Netherlands experienced epidemics of CSF, FMD, and HPAI in a period of 7 years. ${ }^{21,88,107}$ These epidemics had a devastating impact in terms of animal welfare, economics, and societal outcry and disturbance. This was at a time when preventive use of vaccines against FMD and CSF had been prohibited in the EU and mass culling of infected and atrisk animals was the common means of controlling the spread of disease. Probably the most important technological development for animal disease control has been the development of effective vaccines for all animal diseases that target livestock, ${ }^{20}$ and vaccines are now designed so that a vaccinated animal can be reliably distinguished from a previously infected animal (DIVA-principle). Safe and effective FMD vaccine has been available for many decades, but its use in the developed world to respond to accidentally or deliberately introduced disease is not very common. ${ }^{106,108}$

A recent study ${ }^{109}$ indicated that emergency vaccination against FMD in densely populated livestock areas in the Netherlands with more than 4 farms $/ \mathrm{km}^{2}$ can halt the epidemic as rapidly as preemptive culling, while the total number of farms to be culled is reduced by a factor of 4 . Furthermore, it was shown that vaccination and preemptive culling strategies yield comparable numbers of undetected infected animals after final screening. ${ }^{110}$ In a recent update of the Dutch contingency plan for controlling outbreaks of CSF, emergency vaccination is preferred to large-scale preemptive culling. A study by Backer et al $^{111}$ indicated that emergency vaccination against CSF can be equally effective and as safe as preemptive culling.

Although the use of vaccines against avian influenza in birds has been discouraged over the years, the unprecedented occurrence of outbreaks caused by AI viruses recently has required review of this policy. ${ }^{112}$ A variety of products are now on the market, ranging from inactivated conventional to live recombinant vaccines. The general consensus on the use of vaccination is that if vaccines comply with GMP standards and are properly administered, birds will be more resistant to field challenge.

Despite these technological advances, the actual use of emergency vaccination when needed is still under debate in the Netherlands. ${ }^{113}$ The Dutch Chief Veterinary Officer indicated in 2008 that the government would use an emergency vaccination against CSF when the circumstances demand it-for example, the start of CSF outbreaks in swine-dense areas or a large number of outbreaks in a short period of time after the first case is detected. But there is a great deal of uncertainty about the marketing of meat from emergency (DIVA-)vaccinated animals, and a formal agreement is still far off. It is virtually impossible for a European country affected by a disease outbreak to have all the meat from emergency-vaccinated animals consumed by its own population. Meat from emergency-vaccinated animals has to be exported to other European member states for consumption. Consumers' negative perception of meat from emergency-vaccinated animals might be an obstacle and may also result in a lower value for such meat. This seems ridiculous, because other preventive vaccinations are normally used during the production of food animals without the general public's making a fuss about it. There is a real need for a public information strategy and campaign to prepare the public for such a situation. In sum, before emergency vaccination can be used as a full-fledged, costeffective response instrument after a natural or intentional outbreak, talks among representatives of the livestock industry, slaughterhouses, and retailers, supported by national and international animal health organizations, should come to a satisfactory agreement on how to deal with these hurdles.

\section{Conclusion}

There are many vulnerabilities in the livestock industry that can be exploited by agroterrorists. However, on the other side, we have also shown that various early detection systems have recently been developed for agroterrorism and deliberate spread of animal pathogens in livestock, such as an agroterrorism intelligence cycle, syndromic surveillance programs for intentional spread of animal diseases, and computer-based clinical decision support systems that can be used for early detection of notifiable animal diseases. Furthermore, the development of DIVA-vaccines in the past 10 to 15 years has, in principle, created an excellent 
response instrument to counter intentional animal disease outbreaks. These developments have made our animal agriculture a harder target for agroterrorism. But we cannot relax; there are still many challenges, in particular with respect to integrating first line of defense, law enforcement, and early detection systems for animal diseases.

\section{ACKNOWLEDGMENTS}

This research was executed in the framework of the EU project AniBioThreat (Grant Agreement: Home/2009/ ISEC/AG/191) with financial support from the Prevention of and Fight against Crime Program of the European Union, European Commission-Directorate General Home Affairs. In addition, financial support was provided by the Dutch Ministry of Economic Affairs (WOT project \# 01-001-004: Veterinary Epidemiology and Risk Analysis of notifiable animal diseases). This article reflects the views only of the authors, and the European Commission cannot be held responsible for any use that may be made of the information contained therein.

\section{REFERENCES}

1. Monke J. Agroterrorism: Threats and Preparedness. Washington, DC: Congressional Research Service; 2004. http:// www.fas.org/irp/crs/RL32521.pdf. Accessed February 7, 2012.

2. Hugh-Jones M, Brown CC. Accidental and intentional animal disease outbreaks: assessing the risk and preparing and effective response. Rev Sci Tech 2006;25(1):21-33.

3. Wilson TM, Logan-Henfrey L, Weller R, Kellman B. Agroterrorism, biological crimes, and biological warfare targeting animal agriculture. In: Brown C, Bolin C, eds. Emerging Diseases of Animals. Washington, DC: American Society for Microbiology Press; 2000:23-58.

4. Geissler E, van Courtland Moon JE. Biological and Toxin Weapons: Research, Development and Use from the Middle Ages to 1945. Chemical and Biological Warfare Studies No. 18. Oxford: Oxford University Press, Stockholm International Peace Research Institute [SIPRI]; 1999.

5. Kohnen A. Responding to the Threat of Agroterrorism: Specific Recommendations for the United States Department of Agriculture. BCSIA Discussion Paper 2000-29, Discussion Paper ESDP-2000-04. Cambridge, MA: John F. Kennedy School of Government, Harvard University; October 2000.

6. Yeh JY, Park JY, Cho YS, Cho IS. Animal biowarfare research: historical perspective and potential future attacks. Zoonoses Public Health 2012;59:536-544.

7. Casagrande R. Biological warfare targeted at livestock. BioScience 2002;52:577-581.

8. Deen WA. Trends in American agriculture. Their implications for biological warfare against crop and animal resources. Ann N Y Acad Sci 1999;894:164-167.

9. Franz DR. Foreign animal disease agents as weapons in biological warfare. Ann N Y Acad Sci 1999;894:100-104.
10. Noah DL, Noah DL, Crowder HR. Biological terrorism against animals and humans: a brief review and primer for action. J Am Vet Med Assoc 2002;221:40-43.

11. Von Bredow J, Meyers M, Wagner D, Valdes JJ, Loomis L, Zamani K. Agroterrorism-agricultural infrastructure vulnerability. Ann N Y Acad Sci 1999;894:168-180.

12. Dunn MV. The threat of bioterrorism to U.S. agriculture. Ann N Y Acad Sci 1999;894:184-188.

13. Greger M. The long haul: risks associated with livestock transport. Biosecur Bioterror 2007;5:301-311.

14. Carpenter TE, Christiansen LE, Dickey BF, Thunes C, Hullinger PJ. Potential impact of an introduction of foot and mouth disease into the California State Fair. J Am Vet Med Assoc 2007;231:1231-1235.

15. Chalk P. Agroterrorism: what is the threat and what can be done about it? RB-7565-OSD. Santa Monica, CA: RAND; 2004. http://www.rand.org/content/dam/rand/pubs/research_ briefs/2005/RB7565.pdf. Accessed February 17, 2012.

16. International Symposium on Agroterrorism; April 26-28, 2011; Kansas City, MO. http://www.fbi-isa.org. Accessed July 20, 2012.

17. Brown C. Economic considerations of agricultural diseases. Ann N Y Acad Sci 1999;894:92-94.

18. Carus WS. Bioterrorism and Biocrimes. The Illicit Use of Biological Agents Since 1900. Washington, DC: Center for Counterproliferation Research, National Defense University; 2001. http://www.fas.org/irp/threat/cbw/carus.pdf. Accessed February 7, 2012.

19. Parker HS. Agricultural Bioterrorism: A Federal Strategy to Meet the Threat. McNair Paper 65. Washington, DC: Institute for National Strategic Studies, National Defense University; 2002. http://www.ndu.edu/inss/docUploaded/ McNair65.pdf. Accessed February 8, 2012.

20. Wheelis M, Casagrande R, Madden LV. Biological attack on agriculture: low-tech, high-impact bioterrorism. BioScience 2002;52:569-576.

21. Elbers ARW, Stegeman JA, Moser H, Ekker HM, Smak JA, Pluimers FH. The classical swine fever epidemic 1997-1998 in the Netherlands: descriptive epidemiology. Prev Vet Med 1999;42:157-184.

22. Ozawa Y, Makino S, Park JY, Chang JH, Kim JH, An SH. A review of recent unexpected animal disease events in Japan and Korea and the follow-up action taken. Rev Sci Tech 2006;25:21-33.

23. Keeling M, Woolhouse M, Shaw D, et al. Dynamics of the 2001 foot and mouth disease epidemic: stochastic dispersal in heterogeneous landscape. Science 2001;294:813-817.

24. Stegeman JA, Bouma A, Elbers ARW, van Boven M, de Jong MCM, Koch G. The avian influenza A virus (H7N7) epidemic in the Netherlands in 2003: course of the epidemic and effectiveness of control measures. J Infect Dis 2004;190:2088-2095.

25. Wee SH, Park JY, Joo YS, Lee JH, An SH. Control measures implemented during the 2002 foot and mouth disease outbreak in the Republic of Korea. Vet Rec 2004;154: 600602.

26. Elbers ARW, van der Spek AN, van Rijn PA. Epidemiologic characteristics of bluetongue virus serotype 8 laboratory-confirmed outbreaks in The Netherlands in 2007 and a comparison with the situation in 2006. Prev Vet Med 2009;92:1-8. 
27. Sternberg Lewerin S, Elvander M, Westermark T, et al. Anthrax outbreak in a Swedish beef cattle herd-1st case in 27 years: case report. Acta Vet Scand 2010;52:7.

28. Knutsson R, Elvander M, Olsson Engvall E, Eliasson K, Sternberg Lewerin S. Managing and learning from an anthrax outbreak in a Swedish beef cattle herd. In: Hoorfar J, ed. Case Studies in Food Safety and Authenticity: Lessons from Real-life Situations. Cambridge, UK: Woodhead Publishing Series in Food Science; 2012.

29. Lasley FE. Economics of avian influenza: control versus non-control. In: Proceedings of the Second International Symposium on Avian Influenza; 1986:390-399.

30. Sartore S, Bonfanti L, Lorenzetto M, Cecchinato M, Maragon S. The effect of control measures on the economic burden associated with epidemics of avian influenza in Italy. Poultry Sci 2010;89:1115-1121.

31. Koole B, van Bommel KHM, de Bont CJAM, van Horne PLM, van Leeuwen MGA. Financiële draagkracht pluimveesector en het diergezondheidsfonds. LEI Report no. 6.04.21, The Hague, Netherlands. http://www.lei.dlo.nl/ publicaties/PDF/2004/6_xxx/6_04_21.pdf. Accessed March 21, 2012.

32. Sociaal Economische Raad (SER). De pest en het Productschap. 2003. http://www.ser.nl/nl/publicaties/overzicht $\%$ 20ser\%20bulletin/2003/september\%202003/01.aspx. Accessed February 21, 2012.

33. Bowes VA. After the outbreak: how the British Columbia commercial poultry industry recovered after H7N3 HPAI. Avian Dis 2007;51:313-316.

34. Davison S, Galligan D, Eckart TE, Ziegler AF, Eckroade RJ. Economic analysis of an outbreak of avian influenza, 1997-98. J Am Vet Med Assoc 1999;214:1164-1167.

35. Busani L, Dalla Pozza M, Bonfanti L, Toson M, Ferre $\mathrm{N}$, Marangon S. Intervention strategies for low pathogenic avian influenza control in Italy. Avian Dis 2007;51:470-473.

36. Breitmeyer R E, Whiteford AM, Shere JA. California experience with exotic Newcastle disease: a state and federal regulatory perspective. In: Proceedings of the One Hundred and Seventh Annual Meeting of the United States Animal Health Association, San Diego, CA. Richmond, VA: Pat Campbell and Associates; 2003:65-70.

37. Leslie J. Newcastle disease: outbreak losses and control policy costs. Vet Rec 2000;146:603-606.

38. Lamsens G. Klassieke varkenspest epizoötie 1990. Ministerie van Landbouw, Brussels, Belgium; 1992.

39. Vanthemsche P. Classical swine fever 1993-1994 Belgium. Pig Journal 1996;37:43-53.

40. Mintiens K, Deluyker H, Laevens H, Koenen F, Dewulf J, de Kruif A. Descriptive epidemiology of a classical swine fever outbreak in the Limburg province of Belgium in 1997. J Vet Med [B] 2001;48(2):143-149.

41. Meuwissen MPM, Horst SH, Huirne RBM, Dijkhuizen AA. A model to estimate the financial consequences of classical swine fever outbreaks: principles and outcomes. Prev Vet Med 1999;42:249-270.

42. Tanaka R. Foot-and-mouth disease in Italy. Foreign Animal Disease Report. USDA-APHIS-VS-EP 2003;21(2/3):8-9.

43. Thompson D, Muriel P, Russell D, et al. Economic costs of the foot and mouth disease outbreak in the United Kingdom in 2001. Rev Sci Tech 2002;22(3):675-687.
44. Blake A, Sinclair MT, Sugiyarto G. Quantifying the impact of foot and mouth disease on tourism and the UK economy. Tourism Economics 2003;9(4):449-465.

45. Centraal Plan Bureau (CPB). CPB raamt schade MKZ op 2,8 miljard gulden. Persbericht CPB, 22-4-2001.

46. Ministry of Agriculture, Nature and Food Quality (MANF). Financieel eindverslag bestrijding MKZ-uitbraak 2001. VD.2006/289. June 23, 2006.

47. Yang PC, Chu RM, Chung WB, Sung HT. Epidemiological characteristics and financial costs of the 1997 FMD epidemic in Taiwan. Vet Rec 1999;146:731-734.

48. Foot and mouth disease $-\mathrm{S}$. Korea (18): (KB) bovine. ProMED-mail 20111031.3238. http://www.promedmail. org. Accessed November 28, 2012.

49. Nor MNM, Gan CH, Ong BL. Nipah virus infection in pigs in peninsular Malaysia. Rev Sci Tech 2000;19(1):160-165.

50. Nor M, Ong B. The Nipah virus outbreak and the effect on the pig industry in Malaysia. In: Proceedings of the $16^{\text {th }}$ International Pig Veterinary Society Congress, Melbourne, Australia; September 17-21, 2000;548-550.

51. Veldhuis AGJ, Saatkamp HW, Mourits MCM, de Koeijer AA, Elbers ARW. The economic consequences of the Dutch bluetongue serotype 8 epidemics in 2006 and 2007. Prev Vet Med 2010;93:294-304.

52. Tempelman C, Prins J, Koopmans C. Economische gevolgen van de uitbraak van Q-koorts. SEO Economisch Onderzoek, Amsterdam, 2011.

53. Paarlberg PL, Lee JG, Seitzinger AH. Potential revenue impact of an outbreak of foot and mouth disease in the United States. J Am Vet Med Assoc 2002;220:988-992.

54. Australian Government Productivity Commission. Impact of Foot and Mouth Disease Outbreak on Australia. Research Report. Canberra, Australia: Ausinfo; 2002. http://www. pc.gov.au/_data/assets/pdf_file/0012/10623/footandmouth. pdf. Accessed June 10, 2013.

55. People, Pathogens and Our Planet, Volume 2, The Economics of One Health. Report No. 69145-GLB. Washington, DC: World Bank; 2012. http://www-wds.worldbank.org/external/ default/WDSContentServer/WDSP/IB/2012/06/12/0003330 38_20120612014653/Rendered/PDF/691450ESW0whit0D 0ESW120PPPvol120web.pdf. Accessed June 10, 2013.

56. Elbers ARW, Loeffen WLA, Koch G. Classical swine fever and avian influenza epidemics: lessons learned. Berl MünchTierärtzl Wochenschr 2012;125:21-26.

57. Treadwell TE, Koo D, Kuker K, Khan AS. Epidemiological clues to bioterrorism. Public Health Rep 2003; 118:92-98.

58. Ashford DA, Gomez TM, Noah DL, Scott DP, Franz DR. Biological terrorism and veterinary medicine in the United States. J Am Vet Med Assoc 2000;217:664-667.

59. Wilson TM, Gregg DA, King DJ, et al. Agroterrorism, biological crimes, and biowarfare targeting animal agriculture. Clin Lab Med 2001;21:549-591.

60. Pavlin JA. Epidemiology of bioterrorism. Emerg Infect Dis 1999;5:528-530.

61. US Department of Agriculture (USDA); Animal and Plant Health Inspection Service (APHIS); Veterinary Services. Differentiation of Naturally Occurring From Non-Naturally Occurring Epizootics of Anthrax in Livestock Populations. Washington, DC: USDA; 2007. http://www.aphis.usda.gov/ 
animal_health/emergingissues/downloads/finalanthraxnatural terror.pdf. Accessed June 10, 2013.

62. United Nations. Disarmament. Biological and Toxic Weapons Convention. http://www.unog.ch/80256EE60058 5943/(httpPages)/04FBBDD6315AC720C1257180004B1 B2F?OpenDocument. Accessed July 18, 2012.

63. Clarke NP, Rinderknecht JL. Bioterrorism: intentional introduction of animal disease. Rev Sci Tech 2011;30:131-138.

64. Animal health in the world. World Organization for Animal Health website. http://www.oie.int/en/animal-healthin-the-world/oie-listed-diseases-2012/. Accessed November 29, 2012.

65. Agricultural Bioterrorism Protection Act of 2002. Fed Regist 2005 May 18;70(52):13242-13292. http://www. selectagents.gov/resources/APHISFinalRule.pdf. Accessed February 23, 2012.

66. US Department of Agriculture (USDA); Animal and Plant Health Inspection Service; Centers for Disease Control and Prevention. National Select Agent Registry website. www.selectagents.gov/index.html. Accessed July 21, 2012.

67. Emergency preparedness and response. Bioterrorism agents/ diseases. Centers for Disease Control and Prevention (CDC) website. http://emergency.cdc.gov/agent/agentlistcategory.asp. Accessed November 29, 2012.

68. List of animal pathogens for export control. The Australia Group website. http://www.australiagroup.net/en/animal. html. Accessed July 21, 2012.

69. List of biological agents for export control. The Australia Group website. http://www.australiagroup.net/en/biological_ agents.html. Accessed July 21, 2012.

70. Strengthening chemical, biological, radiological and nuclear security in the European Union - an EU CBRN Action Plan. December 14, 2010. Brussels, Belgium. http://eur-lex. europa.eu/LexUriServ/LexUriServ.do?uri = OJ:C:2012:169E: 0008:0023:EN:PDF. Accessed June 10, 2013.

71. Omoe H. Syndromic surveillance-toward the early detection of infectious disease epidemics. Science and Technology Trends, Quarterly Review 2010;37:9-25. http:// www.nistep.go.jp/achiev/ftx/eng/stfc/stt037e/qr37pdf/STTqr 3701.pdf. Accessed June 10, 2013.

72. Bravata DM, McDonald KM, Smith WM, et al. Systematic review: surveillance systems for early detection of bioterrorism-related diseases. Ann Intern Med 2004;140:910-922.

73. Toner ES, Nuzzo JB, Watson M, et al. Biosurveillance where it happens: state and local capabilities and needs. Biosecur Bioterror 2011;9:321-330.

74. Bush LM, Perez MT. The anthrax attacks 10 years later. Ann Intern Med 2012;156:41-44.

75. Beato SM, Terregino C, Cattoli G, Capua I. Isolation and characterization of an H10N7 avian influenza virus from poultry carcasses smuggled from China into Italy. Avian Pathol 2006;35:400-403.

76. Arzt J, White WR, Thomsen BV, Brown CC. Agricultural diseases on the move early in the third millennium. Vet Pathol 2010;47:15-27.

77. van den Berg T. The role of the legal and illegal trade of live birds and avian products in the spread of avian influenza. Rev Sci Tech 2009;28:93-111.

78. Gilbert M, Xiao X, Domenech J, Lubroth J, Martin V, Slingenbergh J. Anatidae migration in the western Pale- arctic and spread of highly pathogenic avian influenza H5NI virus. Emerg Infect Dis 2006;12:1650-1656.

79. Wooldridge M, Hartnett E, Cox A, Seaman M. Quantitative risk assessment case study: smuggled meats as disease vectors. Rev Sci Tech 2006;25:105-117.

80. Hong K-O, Lee G-H, Pak SI. A quantitative modelling approach to estimate the risks posed by the smuggled animal products contaminated with foot and mouth disease virus. Korean J Vet Res 2005;45:223-231.

81. Croddy E. Foot and mouth disease - Taiwan: present situation. ProMED-mail website. 2001-05-01: 20010501.0847. http://www.promedmail.org/?archiveid $=20010501.0847$. Accessed February 26, 2012.

82. Chaber A, Allebone-Webb S, Lignereux Y, Cunningham AA, Rowcliffe JM. The scale of illegal meat importation from Africa to Europe via Paris. Conserv Lett 2010;3:1-7.

83. Breeze RG. Technology, public policy and control of transboundary livestock diseases in our lifetimes. Rev Sci Tech 2006;25(1):271-292.

84. Rohn E, Erez G. Fighting agro-terrorism in cyberspace: a framework for intention detection using overt electronic data sources. In: Rothkrantz L, Ristvej J, Franco Z, eds. Proceedings of the 9th International ISCRAM Conference. Vancouver, Canada; April 2012. http://www.iscramlive.org/ISCRAM 2012/proceedings/261.pdf. Accessed July 18, 2012.

85. Schmitt GR. Agroterrorism-why we're not ready: a look at the role of law enforcement. NIJ Journal 2007;257: 36-39.

86. Moats JB. Agroterrorism: A Guide for First Responders. College Station, TX: Texas A\&M University Press; 2007.

87. Criminal Investigation Handbook for Agroterrorism. Washington, DC: FBI; FDA; USDA; 2008.

88. Elbers ARW, Fabri T, de Vries TS, de Wit JJ, Pijpers A, Koch G. The highly pathogenic Avian Influenza A (H7N7) virus epidemic in the Netherlands: lessons learned from the first five outbreaks. Avian Dis 2004;48: 691-705.

89. Bartels CJM, Kock P, Middelesch H, Wouda W, Van Wuijckhuise L, Van der Zwaag H. Cattle health surveillance in the Netherlands: on how to combine anecdotal and census data. In: Proceedings of the 11th Symposium of the International Society for Veterinary Epidemiology and Economics; Cairns, Australia; 2006. www.sciquest.org.nz. Accessed March 3, 2012.

90. Vourc'h G, Barnouin J. How to improve the detection of animal emerging diseases? A two-level (veterinarian/farmer) approach based on an Internet-Oracle database. 10th International Symposium for Veterinary Epidemiology and Economics; Viña Del Mar, Chile; November 17-21, 2003. www.sciquest.org.nz. Accessed March 3, 2012.

91. De Groot BD, Spire MF, Sargeant JM, Robertson DC. Preliminary assessment of syndromic surveillance for early detection of foreign animal disease incursion or agri-terrorism in beef cattle populations. In: Proceedings of the 10th International Symposium for Veterinary Epidemiology and Economics; Viña Del Mar, Chile; November 17-21, 2003. www.sciquest.org.nz. Accessed March 3, 2012.

92. McIntyre LH, Davies PR, Alexander G, et al. VetPADveterinary practitioner aided disease surveillance system. In: 
Proceedings of the 10th International Symposium for Veterinary Epidemiology and Economics; Viña Del Mar, Chile; November 17-21, 2003. www.sciquest.org.nz. Accessed March 3, 2012.

93. Wenzel J. New Mexico ALIRT and syndromic surveillance. Western Dairy News 2010;10(9):143-144.

94. Elbers ARW, Koch G, Bouma A. Performance of clinical signs in poultry for the detection of outbreaks during the avian influenza A (H7N7) epidemic in the Netherlands in 2003. Avian Pathol 2005;34:181-187.

95. Wester J. The fight against contagious animal diseases between 1870-1900. In: Wester J, ed. History of Veterinary Science. Utrecht, the Netherlands: Hoonte Publisher; 1939: 351-382.

96. Elbers ARW, Bouma A, Stegeman JA. Quantitative assessment of the quality of clinical signs for the detection of classical swine fever outbreaks. Vet Microbiol 2002;85:323-332.

97. Capua I, Marangon S. The avian influenza epidemic in Italy, 1999-2000. Avian Pathol 2000;29:289-294.

98. Canadian Food Inspection Agency (CFIA). In: Lees W, ed. Comprehensive Report on the 2004 Outbreak of High Pathogenicity Avian Influenza (H7N3) in the Fraser Valley of British Columbia, Canada. CFIA, 2004. http://www.inspection. gc.ca/english/anima/heasan/disemala/avflu/2004rep. June 28, 2012.

99. Gibbens JC, Sharpe CE, Wilesmith JW, et al. Descriptive epidemiology of the 2001 foot-and-mouth disease epidemic in Great Britain: the first five months. Vet Rec 2001;149: 729-743.

100. Elbers ARW, Gorgievski-Duijvesteijn MJ, van der Velden PG, Loeffen WLA, Zarafshani K. A socio-psychological investigation into bottlenecks and incentives concerning reporting a clinically suspect situation aimed at improving early detection of Classical Swine Fever outbreaks. Vet Microbiol 2010;142:108-118.

101. Elbers ARW, Gorgievski-Duijvesteijn MJ, Zarafshani K, Koch G. To report or not to report: a psychosocial investigation aimed at improving early detection of Avian Influenza outbreaks. Rev Sci Tech 2010;29(3): 435-449.

102. Elbers ARW, Gorgievski-Duijvesteijn MJ, van der Velden PG, Loeffen WLA. A-specific clinical signs in pigs and use of exclusion diagnostics for classical swine fever: a survey among pig farmers and veterinary practitioners. Tijdschr Diergeneeskd 2007;132:240-245.

103. Krieger R. Zur Bekämpfung der Klassischen Schweinepest. Fachtagung der Zentralverband der Deutschen Schweine- produktion e.V. (ZDS), 11. Dezember 2006, Kassel, Deutschland.

104. Backer J, Spierenburg M, van der Spek A, Elbers ARW. Severe clinical problems lasting several weeks on a multiplier pig farm: what if it had been classical swine fever? Tijdschr Diergeneeskd 2010;135:750-756.

105. Knutsson R. Diagnostic bioterrorism response strategies. In: Morse SA, ed. Bioterrorism. Rijeka, Croatia: InTech; 2012: 65-82.

106. Nara PL. The status and role of vaccines in the U.S. Food Animal Industry. Implications for biological terrorism. Ann N Y Acad Sci 1999;894:206-217.

107. Bouma A, Elbers ARW, Dekker A, et al. The foot-andmouth disease epidemic in the Netherlands in 2001. Prev Vet Med 2003;57:155-166.

108. Breeze R. Agroterrorism: betting far more than the farm. Biosecur Bioterror 2004;2(4):251-264.

109. Backer JA, Hagenaars TJ, Nodelijk G, van Roermund HJW. Vaccination against foot-and-mouth disease. I: epidemiological consequences. Prev Vet Med 2012;107: 27-40.

110. Backer JA, Engel B, Dekker A, van Roermund HJW. Vaccination against foot-and-mouth disease. II: regaining FMD-free status. Prev Vet Med 2012;107:41-50.

111. Backer JA, Hagenaars TJ, van Roermund HJW, de Jong MCM. Modelling the effectiveness and risks of vaccination strategies to control classical swine fever epidemics. $J R$ Soc Interface 2009;6:849-861.

112. Capua I, Alexander DJ. Avian influenza vaccines and vaccination in birds. Vaccine 2008;26S:D70-D73.

113. Vermaas M. Vaccination against classical swine fever is efficient, but the consequences for the market are uncertain (in Dutch). Agrarisch Dagblad, 5 November 2008.

Manuscript received December 13, 2012;

accepted for publication April 10, 2013.

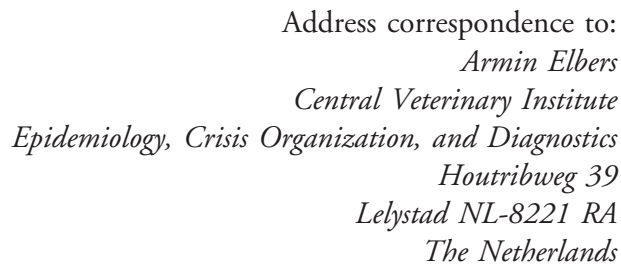

E-mail: armin.elbers@wur.nl 